\title{
Agglutination of Blastospores of Candida albicans by Concanavalin A and its Relationship with the Distribution of Mannan Polymers and the Ultrastructure of the Cell Wall
}

\author{
By ANTONIO CASSONE, ELENA MATTIA AND \\ LORETTA BOLDRINI \\ Institute of Microbiology, Medical Faculty, University of Rome, \\ 00100 Rome, Italy
}

(Received 22 August 1977)

\begin{abstract}
Blastospores of Candida albicans were readily agglutinated by Concanavalin A (Con A) owing to the specific binding of this lectin to the mannan receptors of the cell surface. When mannan was extracted from the cell wall by neutral buffers, alkali and acid, the agglutination was decreased or lost depending on the degree of extraction. A relatively mild alkali treatment was sufficient to derange the multilayered wall organization and transform it into a uniform, medium-density structure having about the same thickness as the untreated wall. After a more drastic extraction, all the electron-dense components of the wall were lost, the residual, alkali-insoluble wall fabric being completely electron-transparent and of about the same thickness as the inner wall region of untreated cells.

Thiol-reducing agents like mercaptoethanol or dithiothreitol also extracted wall materials, an effect which was enhanced by pronase. After dithiothreitol-pronase treatment, the outer wall layers were removed but the inner wall region was not apparently damaged and some electron-dense components remained. None of these treatments significantly affected blastospore agglutination by Con $\mathrm{A}$ - this was reduced (but not abolished) only by the sequential action of pronase and helicase, which led to sphaeroplast formation. These sphaeroplasts showed a varied amount of residual wall consisting of evenly distributed, fibrogranular components.

Two main conclusions were drawn from these results: (i) mannan polymers extend throughout the wall of the blastospore of C. albicans; (ii) the layering of the wall, as seen by ordinary fixation and staining for electron microscopy, essentially reflects the distribution of the various alkali-soluble complexes, at different levels, both over and in the rigid, glucan-chitin matrix.
\end{abstract}

\section{INTRODUCTION}

Concanavalin A (Con A) is a plant lectin which can agglutinate a wide variety of cellular types, including many micro-organisms and, as mentioned by Lis \& Sharon (1973), yeast cells. This protein specifically reacts with several polysaccharides, mainly of the $\alpha$-D configuration, the extent of binding depending on the degree of saccharide branching (Goldstein, Hollerman \& Merrick, 1965). So \& Goldstein (1968) showed that yeast mannans are among the polysaccharides most tenaciously bound by Con A, and Tkacz and co-workers used fluorescein-conjugated Con A to stain specifically yeast mannan (Tkacz, Cybulska \& Lampen, 1971) and to detect the sites of new mannan insertion during cell wall growth in Saccharomyces cerevisiae (Tkacz \& Lampen, 1972).

We have studied the agglutination of blastospores (Y-forms) of Candida albicans by Con A mainly as a possible tool to reveal the presence and the distribution through the cell wall 
of mannan polymers, the only macromolecular complexes in the C. albicans wall which are expected to crosslink extensively with Con A (So \& Goldstein, 1968; Tkacz, et al. 1971). Thus, the ultrastructure of the wall after various chemical and enzymic treatments affecting both mannan content and Con A-agglutination has been observed in an attempt to gain insight into the relationship between mannan components and the very complex wall layering seen in C. albicans (Djaczenko \& Cassone, 1972; Winner, 1972; Cassone, Simonetti \& Strippoli, 1973).

While this paper was in an advanced stage of preparation, a report appeared showing that $\mathrm{Y}$-forms of $C$. albicans are in fact agglutinated by Con A and discussing the effect of temperature on this phenomenon (Janson \& Paktor, 1977).

\section{METHODS}

Organisms and growth conditions. Candida albicans strains $\mathrm{A}_{44}$ and $\mathrm{A}_{1 \mathrm{~F}}$, Saccharomyces cerevisiae $\mathrm{ATCC} 4098$ and Rhodotorula glutinis, all from the collection of the Institute of Microbiology, University of Rome, were used throughout this study. Unless otherwise stated the experiments refer to strain $\mathrm{A}_{44}$ of C. albicans.

Organisms were generally grown in liquid Winge medium (Garcia-Mendoza \& Novaes-Ledieu, 1968) but some agglutination experiments were done with cultures grown on solid Sabouraud or yeast morphology agar (Difco) at $37^{\circ} \mathrm{C}$. Organisms grew on all these media as essentially pure blastospore populations, and Con A-agglutination and the ultrastructural patterns of the wall were similar after growth on any of them. Blastospores were harvested during the late-exponential or early-stationary phase of growth and washed free of medium for further experimental work. Cell dry weight was determined essentially as described by Nishioka \& Silva-Hutner (1974).

Test for Con A-agglutination and its quantitative scoring. The agglutination of washed blastospores with Con A (Con A-agglutination) was observed in test tubes containing, unless stated otherwise, $10^{7} \mathrm{cells}^{-1}$

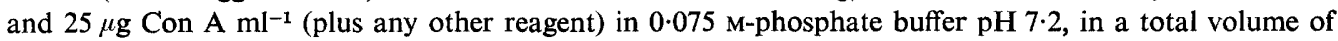
$0.5 \mathrm{ml}$. Tubes were incubated at $28{ }^{\circ} \mathrm{C}$ for up to $2 \mathrm{~h}$. At intervals during incubation, gently pipetted drops of incubation mixture were examined by phase-contrast microscopy using a low-power objective $(15 \times)$.

To score the extent of agglutination, the following criteria were used. Agglutination was scored as positive $(+1)$ when several clusters of at least 5 to 7 cells were present; the maximum score $(+5)$ was given when many clusters with apparently more than 25 cells were present in any microscopic field, so that the majority of cells appeared to have been agglutinated. The intermediate values were scored accordingly, taking account of both the number of clusters and the number of cells in each cluster. Care was taken not to consider as 'agglutinates' the pseudomycelia, although these were rare in the inoculated blastospore population. Groups of cells simply lying side by side but without 'clustering' in all spatial directions were not considered as clusters.

These criteria for estimating the Con A-agglutination are essentially those adopted for mammalian cell agglutination (Inbar \& Sachs, 1969).

Polysaccharide extraction and assays. Alkali extraction of whole cells was performed in two sequential steps. In the first, milder step, cells at a density of $1 \mathrm{mg}$ dry wt ml ${ }^{-1}$ were suspended in $1.0 \mathrm{M}-\mathrm{NaOH}$ and slowly agitated for $45 \mathrm{~min}$ at room temperature (Alk-1 cells); in the second, more drastic step, cells were heated at $85^{\circ} \mathrm{C}$ in $0.6 \mathrm{M}-\mathrm{NaOH}$ for five periods of $4 \mathrm{~h}$ each, followed by overnight incubation at $20^{\circ} \mathrm{C}$ in the same solvent (Alk-2 cells). Acid extraction was carried out by treating Alk-2 cells with hot $0.5 \mathrm{M}$-acetic acid for $12 \mathrm{~h}$ at $85^{\circ} \mathrm{C}$ with intermittent water washing of the cells every $4 \mathrm{~h}$ (Alk+Acid cells). All samples were carefully washed and neutralized before further experimental work.

In other experiments, mannan and other soluble components were extracted from whole cells with hot citrate buffer, essentially as described by Ballou and co-workers (Thieme \& Ballou, 1972; Ballou, 1976). From both alkali and citrate extracts mannan was precipitated as a copper complex, purified and assayed as described by Thieme \& Ballou (1972). Other alkali-soluble components were extensively dialysed against $0.05 \mathrm{M}$-phosphate buffer $\mathrm{pH} 7.2$ at $4{ }^{\circ} \mathrm{C}$ and concentrated before testing their effect on Con A-agglutination.

Treatment with reducing agents and enzymes. Washed blastospores at a concentration of $1 \mathrm{mg}$ dry wt $\mathrm{ml}^{-1}$ were suspended in $0.05 \mathrm{M}$-Tris $/ \mathrm{HCl}$ buffer $\mathrm{pH} 7.4$ containing $0.6 \mathrm{M}-\mathrm{KCl}$ as osmotic stabilizer and $12 \mathrm{~mm}$ dithiothreitol (DTT) or 0.2 M-mercaptoethanol. Differences in the effects of these two SH-reducing agents were not significant and all results refer to experiments performed with dithiothreitol. After $30 \mathrm{~min}$ treatment with this reagent at $37^{\circ} \mathrm{C}$, samples were treated with pronase $\left(100 \mu \mathrm{g} \mathrm{ml}^{-1}\right)$ for $60 \mathrm{~min}$ at $37^{\circ} \mathrm{C}$ and compared with controls incubated without pronase.

Some samples were further incubated for $90 \mathrm{~min}$ in Tris $/ \mathrm{KCl}$ buffer with helicase, a mixture of glycolytic enzymes from snail gut juice, at a concentration of $150 \mu \mathrm{g} \mathrm{ml}^{-1}$. After each treatment, cells were carefully 


\section{Table 1. Factors affecting the extent of Con A-agglutination of untreated, heat-killed and alkali/acid-extracted blastospores of Candida albicans}

Agglutination tests were carried out $\left(10^{7}\right.$ cells $\mathrm{ml}^{-1}, 28^{\circ} \mathrm{C}, \mathrm{pH} 7 \cdot 2$, unless stated otherwise $)$ and scored as described in Methods. In some experiments, Con A $\left(50 \mu \mathrm{g} \mathrm{ml}^{-1}\right)$ was preincubated with methyl $\alpha$-D-mannopyranoside $(\alpha \mathrm{MM})$ in buffer at $28^{\circ} \mathrm{C}$ for $30 \mathrm{~min}$ before cells were added for the agglutination test.

\begin{tabular}{|c|c|c|c|c|c|c|c|c|c|c|c|}
\hline \multirow[b]{2}{*}{ Treatment of blastospores } & \multicolumn{4}{|c|}{ Con $\mathrm{A}$ concn $\left(\mu \mathrm{g} \mathrm{ml}^{-1}\right)$} & \multicolumn{4}{|c|}{ Temperature $\left({ }^{\circ} \mathrm{C}\right) *$} & \multicolumn{3}{|c|}{$\alpha \mathrm{MM}$ concn $(\mathrm{mM})$} \\
\hline & 10 & 30 & 50 & 200 & 4 & 18 & 28 & 37 & 1 & 5 & 10 \\
\hline Untreated $\left(10^{6}\right.$ cells $\left.\mathrm{ml}^{-1}\right)$ & +1 & +3 & +5 & +5 & ND & ND & ND & ND & ND & ND & ND \\
\hline Untreated $\left(10^{7}\right.$ cells $\left.\mathrm{ml}^{-1}\right)$ & +2 & +5 & +5 & +5 & 0 & +2 & +5 & +4 & +3 & 0 & 0 \\
\hline Alk-1 treated & +1 & +4 & +5 & ND & 0 & +2 & +4 & +4 & +3 & 0 & 0 \\
\hline Alk-2 treated & 0 & 0 & +1 & +1 & ND & ND & ND & ND & ND & 0 & 0 \\
\hline Alk + Acid treated & ND & ND & 0 & 0 & ND & ND & ND & ND & ND & ND & ND \\
\hline Heat-killed $\left(70^{\circ} \mathrm{C}, 30 \mathrm{~min}\right)$ & ND & +4 & +5 & ND & ND & ND & ND & ND & +2 & 0 & 0 \\
\hline
\end{tabular}

ND, Not determined. 0, No agglutination.

* Con A used at $30 \mu \mathrm{g} \mathrm{ml}^{-1}$.

washed with Tris $/ \mathrm{KCl}$ and tested for Con A-agglutination in the same buffer or prepared for electron microscopy.

Electron microscopy. Samples were processed for electron microscopy essentially as described previously (Cassone, 1973; Cassone et al., 1973). Thin sections were cut with Porter-Blum MT2 or LKB III ultramicrotomes, stained with uranyl acetate and lead citrate (Reynolds, 1963) and observed in a Siemens 1A electron microscope operating at 60 to $80 \mathrm{kV}$.

Chemicals. Con A, crystallized three times, was purchased from Miles Yeda, and methyl $\alpha$-D-mannopyranoside was a kind gift of Dr C. Montecucco, Department of Biochemistry, University of Cambridge. Pronase was purchased from Sigma, and helicase from l'Industrie Biologique Française, Gennevilliers, France. All other chemicals were of standard reagent grade.

\section{RESULTS}

Specificity and reversibility of blastospore agglutination by Con A and its dependence on surface mannan component of the cell wall

On addition of Con A to washed blastospores of C. albicans, harvested from either the exponential or stationary phase of growth, a marked agglutination took place (Fig. 1). At a yeast concentration of $10^{7}$ cells $\mathrm{ml}^{-1}$, optimum agglutination was scored with 20 to $30 \mu \mathrm{g}$ Con $\mathrm{A} \mathrm{ml}^{-1}$ after $1 \mathrm{~h}$ incubation in $0.075 \mathrm{M}$-phosphate buffer $\mathrm{pH} 7 \cdot 2$. The optimum temperature was in the range 28 to $30^{\circ} \mathrm{C}$ but significant agglutination was also observed at $37^{\circ} \mathrm{C}$. At $4{ }^{\circ} \mathrm{C}$ no agglutination had occurred after $2 \mathrm{~h}$ incubation with $100 \mu \mathrm{g} \mathrm{Con} \mathrm{A} \mathrm{ml}^{-1}$. From pH 6.2 to 8.4 no significant differences in the rate of agglutination were observed. Killed cells (heated at $70^{\circ} \mathrm{C}$ for $30 \mathrm{~min}$ ) were also agglutinated (Table 1).

To test the specificity of the agglutination the specific Con A ligand, methyl $\alpha-D-m a n n o-$ pyranoside $(\alpha \mathrm{MM})$, was added to the reaction mixture at concentrations in the range 1 to $10 \mathrm{~mm}$. The agglutination by $50 \mu \mathrm{g}$ Con $\mathrm{A} \mathrm{ml}^{-1}$ was completely prevented by preincubation (30 min) of the lectin with $5 \mathrm{mM}-\alpha \mathrm{MM}$ (Table 1). Moreover, the addition of $5 \mathrm{mM}-\alpha \mathrm{MM}$ to agglutinated cells completely reversed the agglutination within $30 \mathrm{~min}$. The concentration of $\alpha \mathrm{MM}$ used to inhibit and reverse the agglutination is in the range shown by many other workers to be effective for binding of $\alpha \mathrm{MM}$ to Con $\mathrm{A}$. The experiments showed that the agglutination of $C$. albicans blastospores by Con A was specifically due to binding of the protein to some components present on the cell surface.

On the basis of the known macromolecular composition of the wall of $C$. albicans (Kessler \& Nickerson, 1959; Chattaway, Holmes \& Barlow, 1968) and of the type of polysaccharide chains specifically bound by Con A (Goldstein et al., 1965), mannan components are the only possible Con A-agglutination mediators. In keeping with these considerations, and in 
accord with the fluorescein-conjugated Con A binding studies of Tkacz et al. (1971), we found that another strain of $C$. albicans $\left(\mathrm{A}_{1 \mathrm{~F}}\right)$ and also Saccharomyces cerevisiae, known to have $\alpha$-mannan exposed on its surface (Bacon et al., 1969; Phaff, 1971), were agglutinated by Con A whereas a Rhodotorula glutinis strain, known not to contain $\alpha$-mannan, was not agglutinated.

To exclude the possibility that soluble, surface-located, unknown wall components were responsible for the agglutination instead of mannan, inhibition tests were performed with both mannan and other non-dialysable components, solubilized by alkali or citrate extractions (see Methods). Con $\mathrm{A}\left(100 \mu \mathrm{g} \mathrm{ml}^{-1}\right)$ preincubated with mannan ( $3 \mathrm{mg}$ mannose $\mathrm{ml}^{-1}$ ) did not agglutinate blastospores, whereas Con A preincubated with all other extracted wall components (essentially some glucan and protein) was still able to induce agglutination (data not shown).

It was concluded that the tetravalent molecule of Con A agglutinated the blastospores of C. albicans by binding to surface-located mannan molecules and cross-bridging them, as for the agglutination in other cellular systems (apart from the different nature of the receptors) (Nicolson, 1974).

\section{Alkali extraction, Con A-agglutination and wall ultrastructure}

The above results prompted us to evaluate the effects of alkali extraction, a procedure known to remove mannan components from yeast walls (Phaff, 1971), on Con A-agglutination and relate them to the appearance of the cell surface in the electron microscope. Two sequential alkali extraction steps were used; the first, milder one (Alk-1) removed only part of the wall mannan, and the second, more drastic one (Alk-2) removed almost all mannan from the wall. The alkali treatment was followed by an acid extraction (see Methods).

After Alk-1 extraction, cells were still strongly agglutinable, but agglutination was minimal after Alk-2 extraction and completely lost after Alk + Acid treatment (Table 1). Alk-1 and Alk-2 treatments released, respectively, about $32 \%$ and more than $90 \%$ of the total extractable mannan from isolated walls (V. Strippoli, personal communication). The slight agglutination detected in Alk-2 cells with $200 \mu \mathrm{g} \mathrm{Con} \mathrm{A} \mathrm{ml}^{-1}$ was specific (see Table 1) and can be interpreted as due to some residual mannan 'trapped' in the glucan-chitin inner wall layers which was removed on subsequent acid extraction. Even hot citrate extraction did not remove all mannan from the wall, as judged by the slight but detectable agglutination after this treatment.

The ultrastructure of the wall of untreated blastospores of $C$. albicans is shown in Figs 2 and $8(a)$. The multilayered wall organization has already been described by Cassone et al. (1973) and confirmed by Chattaway et al. (1976). In particular an outermost, capsule-like component built up of spiky, fibrillar protrusions which, on the basis of the Con A-agglutination tests, should consist essentially of mannan, is clearly visible (Fig. $8 a$ ).

After Alk-1 treatment, the thickness of the wall is about the same as in untreated cells (in spite of a conspicuous diminution of cell volume, as observed by light microscopy). How-

Bar markers represent $10 \mu \mathrm{m}$ in Fig. 1 and $0 \cdot 1 \mu \mathrm{m}$ in Figs 2, 3, 4.

Fig. 1 $(a, b)$. Typical Con A-agglutinates of $C$. albicans blastospores. Note the swelling of some cells of the agglutinate in $(b)$.

Fig. 2. Untreated blastospore of C.albicans showing the multilayered appearance of the wall (W).

Fig. 3. Alk-1 treated blastospores. The thickness of the wall $(W)$ is not substantially different from that of the untreated blastospore (see also Fig. $8 a, b$ ), but the layering and most of the electrondense components of the outer wall have been lost.

Fig. 4. Alk-2 treated blastospores. Note the complete disappearance of electron-dense components and layering from the wall (W). The cell shape does not appear to be grossly distorted but Alk-2 cells, like Alk-1 cells, have a decreased volume. In contrast to Alk-1 cells, the cytoplasmic matrix has been almost completely extracted. 

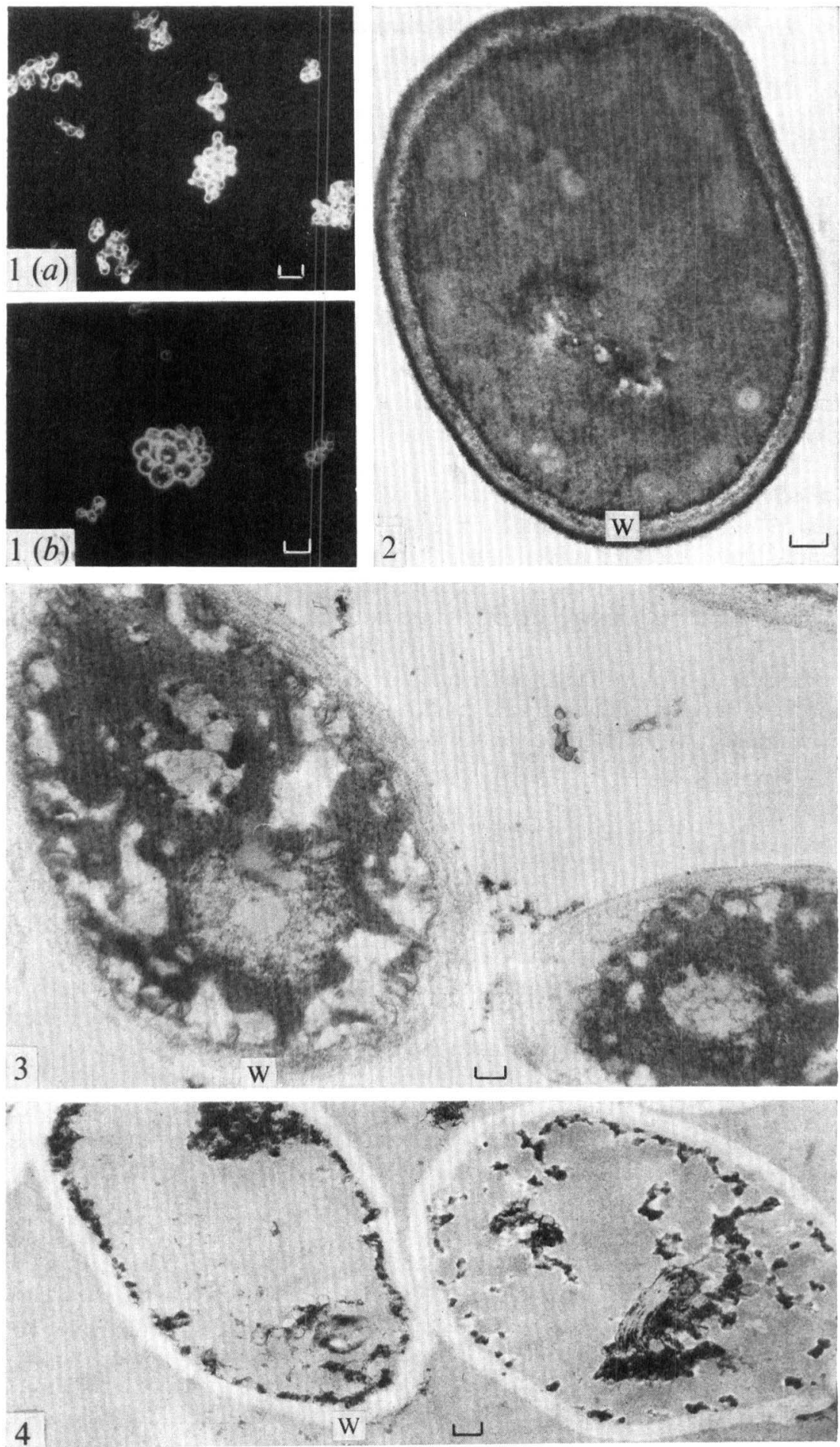

Figs 1-4. For legends see opposite. 


\section{Table 2. Con A-agglutination of blastospores of Candida albicans after dithiothreitol and enzymic treatments}

Agglutination tests were carried out as described in the legend to Table 1.

\begin{tabular}{|c|c|c|c|c|c|}
\hline \multirow[b]{2}{*}{ Treatment of blastospores } & \multicolumn{3}{|c|}{ Con $\mathrm{A}$ conch $\left(\mu \mathrm{g} \mathrm{ml}^{-1}\right)$} & \multicolumn{2}{|c|}{$\alpha \mathrm{MM}$ concn $(\mathrm{mM})$} \\
\hline & 30 & 50 & 100 & 3 & 5 \\
\hline Untreated & +5 & +5 & +5 & 0 & ND \\
\hline DTT treated & +5 & ND & ND & +1 & 0 \\
\hline DTT-pronase treated & +4 & +5 & ND & $\mathbf{u}$ & 0 \\
\hline DTT-pronase-helicase treated & +1 & +4 & +4 & $\mathbf{U}$ & 0 \\
\hline
\end{tabular}

ND, Not detected. 0, No agglutination; U, agglutination uncertain.

ever, the multilayered organization of wall components is lost (Fig. 3) and their electrondensity is decreased (Fig. $8 b$ ). The appearance of the wall of Alk-2 treated cells is shown in Fig. 4. In keeping with the more drastic extraction procedure and the consequent removal of wall materials, the overall wall thickness is markedly reduced, from about $135 \mathrm{~nm}$ in Alk-1 cells to about $85 \mathrm{~nm}$, a value roughly corresponding to the thickness of the inner layers of the untreated wall (Figs 4, 8c and Table 3, see also Djaczenko \& Cassone, 1972). More striking, however, is the total loss of layering apparently caused by the complete removal of the electron-dense components (Figs 4 and $8 c$ ). Apart from further thinning, with associated cell profile deformation, the appearance of the wall of Alk + Acid cells was similar to that of Alk-2 cells.

After Alk-2 treatment all the cytoplasmic content was lost, but the general cell outline and shape were retained showing that conditions leading to the loss of all electron-dense components may not affect the rigid wall fabric which seems to substantially retain its organization.

\section{Wall ultrastructure and Con A-agglutination of blastospores treated with reducing agents and enzymes}

The correlation between Con A-agglutination of blastospores of C. albicans and the location of mannan polymers throughout the yeast wall was further examined after enzymic degradation. As shown in a number of papers and recently emphasized by several workers (Kerridge et al., 1976; Chattaway et al., 1976), hydrolytic enzymes are greatly assisted in their action on $C$. albicans by pretreatment of cells with SH-reducing agents like mercaptoethanol or dithiothreitol (DTT). We have studied the effect of these agents, used alone or in combination with various enzymes, on both Con A-agglutination and ultrastructure. Confirming the observations of Davies \& Wayman (1975; also Davies, personal communication) and Chattaway et al. (1976), both mercaptoethanol and DTT were found to release a large amount of wall components from $C$. albicans blastospores. With added enzymes, the release was greater and, after digestion with DTT plus pronase and helicase, sphaeroplasts were formed (compare Figs 5, 6 and 7). During a series of such treatments, thinning of the wall with degradation of its layers was observed. In particular, after DTT-pronase treatment, the two outer wall layers had been almost completely removed (Fig. 6), a situation looking comparable to that of Alk-2 cells, except that the residual inner layers still had appreciable amounts of electron-dense components (compare Figs $8 c$ and $e$ ). Only a very thin boundary overlaying the inner wall components could be seen on the wall surface after this proteolytic treatment (Fig. 6). Nonetheless, these cells essentially retained Con A-agglutinability (Table 2), as did, although to a lesser extent, helicase-treated cells which showed only a very thin, fibrous wall layer over the plasmalemma (Fig. 7). The majority of these cells had become osmotically sensitive, i.e. sphaeroplasts (Fig. 7, Table 2).

As a very young culture was used for these experiments, all cells were affected by 

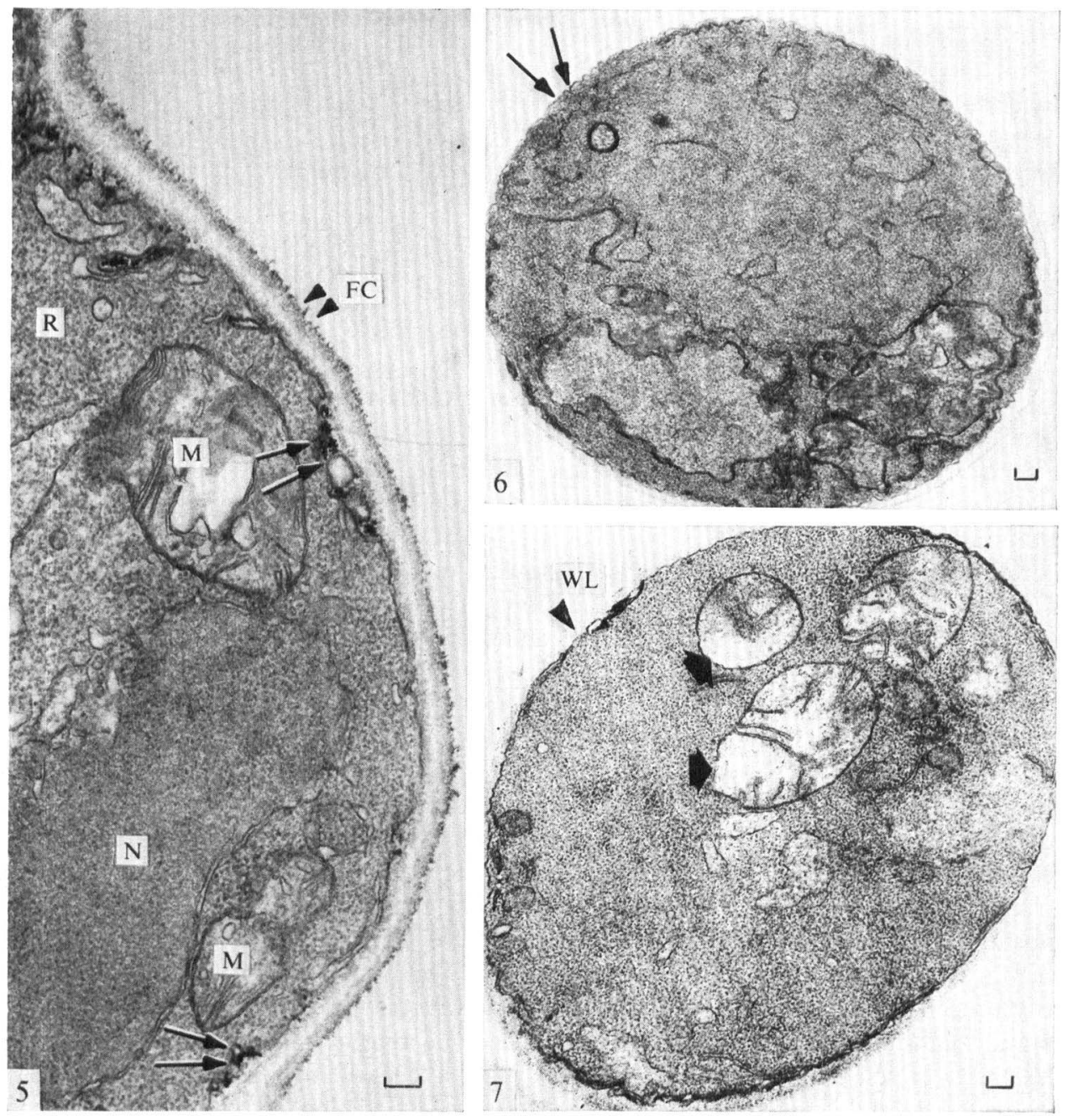

All bar markers represent $0 \cdot 1 \mu \mathrm{m}$.

Fig. 5. Blastospores treated for $3 \mathrm{~h}$ with $12 \mathrm{~mm}$-dithiothreitol. The outermost fibrous wall component has been removed and the basal electron-dense layer has been extracted so that it appears to form a discontinuous 'fuzzy coat' (FC). Note also that the consistency of the innermost periplasmic layer is much reduced (cf. the control, Fig. 2, and Fig. $8 a, d$ ) and that the compound seems to have penetrated deeply into the periplasmic space, being strongly stained by metals (arrows). The extraction of wall materials allows the fixatives and stains to penetrate the cell with greater efficiency so the overall cell preservation and the contrast of organelles are improved. See also Figs 6 and 7. $\mathrm{N}$, Nucleus; R, ribosomes; $\mathrm{M}$, mitochondria.

Fig. 6. The effect of DTT-pronase treatment on a blastospore. A compact, electron-transparent layer remains, surrounded by a thin, electron-dense line. Note the normal appearance of the plasmamembrane (arrows).

Fig. 7. The effect of DTT-pronase-helicase treatment on a blastospore. The residual wall layer (WL) consists of a well-defined, loose network. The inner, glucan-chitin wall fabric is substantially affected, so that this form is osmotically fragile (note the mitochondrial swelling indicative of osmotic impairment, arrows). 
Table 3. The effect of various treatments on electron-dense components, wall thickness and layering in Candida albicans

\begin{tabular}{|c|c|c|c|}
\hline Treatment of blastospores & Electron-dense components & Layering & $\begin{array}{c}\text { Wall } \\
\text { thickness* } \\
(\mathrm{nm})\end{array}$ \\
\hline Untreated & Mainly outer & Present & $135 \pm 12$ \\
\hline Alk-1 treated & $\begin{array}{l}\text { Low-density material evenly } \\
\text { distributed }\end{array}$ & Absent & $132 \pm 10$ \\
\hline Alk-2 treated & Absent $\uparrow$ & Absent & $85 \pm 7$ \\
\hline DTT treated & Residual, outer & Present & $93 \pm 14$ \\
\hline DTT-pronase treated & Scanty, mainly outer & Present, scanty & $85 \pm 6$ \\
\hline $\begin{array}{l}\text { DTT-pronase-helicase } \\
\text { treated }\end{array}$ & $\begin{array}{l}\text { Low density, evenly } \\
\text { distributed, fibrogranular }\end{array}$ & Absent & $50 \pm 18$ \\
\hline
\end{tabular}

the treatments with DTT and enzymes to a similar degree (confirmed by electron microscopic observations) and during the experimental period (about $150 \mathrm{~min}$ ) cell viability was substantially preserved ( $>95 \%$ ).

For ease of comparison of the effects of the various chemical and enzymic treatments on C. albicans wall structure, higher magnifications of wall profiles under the electron microscope are grouped together in Fig. 8. The effect of the treatments on thickness, electron density and layering of the wall are summarized in Table 3.

\section{DISCUSSION}

We have shown that Y-forms of Candida albicans are strongly and specifically agglutinated by the plant lectin Con A, confirming the very recent report of Janson \& Paktor (1977). In agreement with Tkacz et al. (1971), we have also shown that wall mannan components are the receptors for Con A binding and the subsequent agglutination. In animal cells, there is a substantial body of evidence that a 'clustering' of Con A receptors is one of the prerequisites for cells to agglutinate (Nicolson, 1974). The Con A receptors in C. albicans are clearly established on the cell surface in such a way that cross-bridge formation among cells and agglutination are possible in the absence of any lateral receptor movement. The high density of cell surface mannan probably plays a key role in determining the ease with which cells are agglutinated. By its very nature, the test of Con A-agglutination described here is crude and merely qualitative, so it cannot give any information about the amount or type of mannan present on the surface of the organism. Furthermore, it should be remembered that the binding of receptors to Con A is necessary but not always sufficient for agglutination (Nicolson, 1974). Thus, lack of agglutination would not necessarily mean that the specific binding components are absent.

Nevertheless, a strict positive parallelism seems to exist between the presence of mannan receptors and cell agglutination in $C$. albicans as judged by the observation that only conditions leading to substantial mannan extraction are followed by a decrease or loss of Con Aagglutinability (see the results of alkali and acid extraction, or extraction with buffers). Under conditions in which no cell agglutination has been detected, very little, if any, mannan could be found in the wall.

Electron microscopic investigation demonstrated that, with the progression of alkali extraction, the wall loses its ordered layering and, eventually, all its electron-dense components. Under the conditions of alkali extraction employed, the bulk of wall glucan and chitin (which are alkali-insoluble) and possibly also some innermost protein remain in the wall. It is clear, therefore, that these 'rigid' components do not directly contribute to the wall layering since they are not stainable using the conventional fixation and staining 

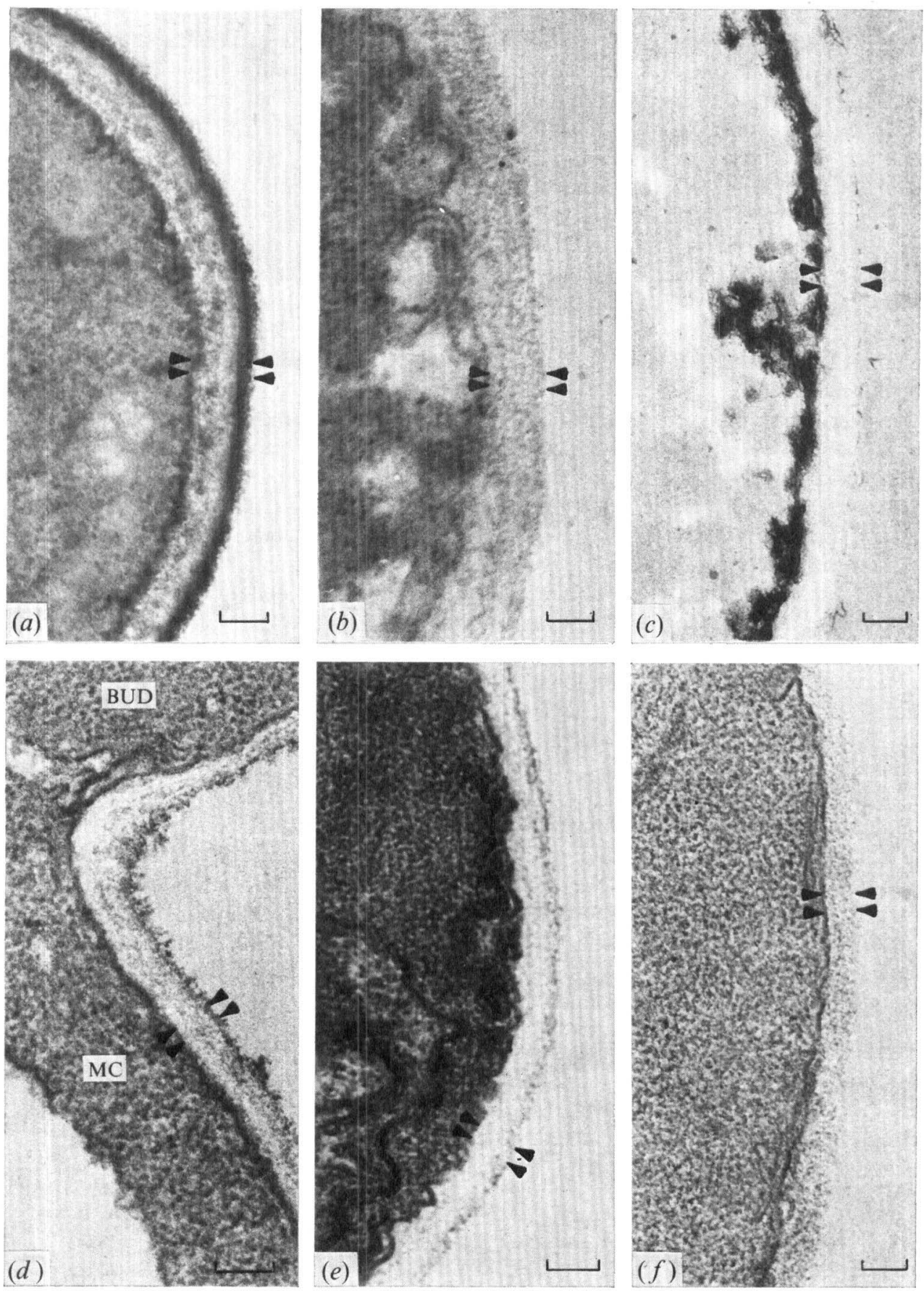

Fig. 8. Walls of C. albicans after different treatments: (a) untreated; (b) Alk-1 treated; (c) Alk-2 treated; $(d)$ DTT treated (MC, mother cell); $(e)$ DTT-pronase treated; $(f)$ DTT-pronase-helicase treated. The wall thickness is indicated by arrowheads. Bar markers represent $0 \cdot 1 \mu \mathrm{m}$. 
procedures for thin sections, although they can be visualized by suitable cytochemical reactions (unpublished results). It seems likely that mannan-protein complexes have a major role in wall layering, with the possible participation of some soluble glucan and unconjugated proteins. If a true 'organizational' separation among these soluble components exists, it should be possible to detect it using Con A labelled with ferritin or other electron-dense markers. Work is in progress to detect mannan polymers using the Con A-ferritin technique (Nicolson, 1974).

After prolonged alkali extraction, the wall thickness was approximately two-thirds that of unextracted cells. Since there is no evidence for an artefactual contraction of the wall during the extraction, we conclude that much of the extracted material overlays the alkaliinsoluble inner wall fabric. This material would, therefore, correspond to the two outer layers seen in untreated cells and substantially digested by DTT-pronase treatment. Coupled with the finding that Con A-agglutination is dramatically reduced after Alk-2 extraction, one might be tempted to deduce that essentially all mannan components are located in these outer layers.

However, the results of the experiments using DTT and enzymes suggest that the distribution of mannan components in the wall of C. albicans is far more complex. After DTTpronase treatment, all outer layers are also substantially removed and the wall is as thin as that of Alk-2 cells, yet cells are strongly agglutinated with Con A. Even after extensive wall degradation by helicase enzymes, eventually leading to sphaeroplast formation, some agglutination persists. Interestingly, all these treatments at variance with Alk-2 extraction, do not completely remove the electron-dense 'inner' components of the wall. Thus, the marked diminution in Con A-agglutinability after Alk-2 treatment and its loss after Alk+ Acid treatment, are due not solely to the loss of the outer mannan-rich layers but also to the extraction of other mannan components which are 'embedded' in the inner wall layers, including probably also the periplasmic space.

Taken together, these results strongly support the idea that mannan polymers span the wall of the Y-form of $C$. albicans. An attractive hypothesis which also follows from these studies is that the complex wall layering of this organism essentially reflects differences in the amount and, possibly, organization and functions of mannan and protein complexes. Therefore, the classical distinction between the soluble 'plastic' wall components and the insoluble 'rigid' matrix (Bartnicki-Garcia, 1968) would have its counterpart in ultrastructure between electron-dense, layered and electron-transparent, uniform components. To explore more fully this model of organization, which could contribute to a better understanding of the dimorphic transition in C. albicans, further refinements in the cytochemical techniques for electron microscopic visualization of wall structures are necessary.

We thank all the researchers of the mycological group in the Sub-Department of Chemical Microbiology of the University of Cambridge for their interest in this work and the help given in preparing this manuscript. In particular, one of us (A.C.) is indebted to Dr D. Kerridge for many helpful discussions on the subject of the paper.

\section{REFERENCES}

BaCon, J. S. D., FARmer, V. C., Jones, D. \& TAYlor, I. F. (1969). The glucan components of the cell wall of baker's yeast (Saccharomyces cerevisiae) considered in relation to its ultrastructure. Biochemical Journal 114, 557-567.

BALlou, C. (1976). Structure and biosynthesis of the mannan components of the yeast cell envelope. Advances in Microbial Physiology 14, 93-158.
BARTNICKI-GARCIA, S. (1968). Cell wall chemistry, morphogenesis and taxonomy of fungi. Annual Review of Microbiology 22, 87-108.

CASSONE, A. (1973). Improved visualization of wall ultrastructure in Saccharomyces cerevisiae. Experientia 29, 1303-1305.

Cassone, A., Simonetti, N. \& Strippoli, V. (1973). Ultrastructural changes in the wall during germ- 
tube formation from blastospores of Candida albicans. Journal of General Microbiology 77, 417-426.

Chattaway, F. W., Holmes, M. R. \& Barlow, A. J. E. (1968). Cell wall composition of the mycelial and blastospore forms of Candida albicans. Journal of General Microbiology 51, 367376.

Chattaway, F. W., Shenolikar, S., O'Reilly, J. \& Barlow, A. J. E. (1976). Changes in the cell surface of the dimorphic forms of Candida albicans by treatment with hydrolytic enzymes. Journal of General Microbiology 95, 335-347.

Davies, R. \& Wayman, F. J. (1975). The effect of thiols on Saccharomyces fragilis. Antonie van Leeuwenhoek 41, 33-58.

Djaczenko, W. \& CAssone, A. (1972). Visualization of new ultrastructural components in the cell wall of Candida albicans with fixatives containing TAPO. Journal of Cell Biology 52, 186-190.

Garcia-Mendoza, C. \& Novaes-Ledieu, M. (1968). Chitin in the new wall of regenerating protoplasts of Candida utilis. Nature, London 220, 1035.

Goldstein, I. J., Hollerman, C. E. \& Merrick, J. M. (1965). Protein-carbohydrate interaction. I. The interaction of polysaccharides with Concanavalin A. Biochimica et biophysica acta 97, 68-76.

INBAR, M. \& SACHS, L. (1969). Interactions of carbohydrate-binding protein Concanavalin A with normal and transformed cells. Proceedings of the National Academy of Sciences of the United States of America 63, 1418-1425.

Janson, V. K. \& Paktor, J. A. (1977). The effect of temperature on Concanavalin A mediated agglutination of cells with rigid receptors. Biochimica et biophysica acta 467, 321-326.

Kerridge, D., Кoh, T. Y., MarriotT, M. S. \& Gale, E. F. (1976). The production and properties of protoplasts from the dimorphic yeast Candida albicans. In Microbial and Plant Protoplasts, pp. 23-38. Edited by J. F. Peberdy, A. H. Rose, H. J. Rogers and E. C. Cocking. London and New York: Academic Press.
Kessler, G. \& Nickerson, W. J. (1959). Glucomannan-protein complexes from cell walls of yeasts. Journal of Biological Chemistry 234, 22812285.

Lis, H. \& Sharon, N. (1973). The biochemistry of plant lectins (phytohemagglutinins). Annual Review of Biochemistry 42, 541-574.

NicOLSoN, G. L. (1974). The interaction of lectins with animal cell surfaces. International Review of Cytology 39, 89-100.

Nishioka, Y. \& Silva-Hutner, M. (1974). Dimorphism, sensitivity to nystatin and acriflavin uptake in a strain of Candida albicans grown with glutamate as sole nitrogen and carbon source. Sabouraudia 12, 295-301.

PhafF, H. J. (1971). Structure and biosynthesis of yeast cell envelope. In The Yeasts, vol. II, pp. 135210. Edited by A. H. Rose and J. S. Harrison. London and New York: Academic Press.

ReYnolds, E. S. (1963). The use of lead citrate at high $\mathrm{pH}$ as an electron-opaque stain in electron microscopy. Journal of Cell Biology 17, 208-212.

So, L. L. \& Goldstein, I. L. (1968). Protein-carbohydrate interaction. XII. The interaction of Concanavalin A with $\alpha$-mannans from a variety of microorganisms. Journal of Biological Chemistry 248, 2003-2007.

Thieme, T. R. \& Ballou, C. E. (1972). Subunit structure of the phosphomannans from Kloeckera brevis yeast cell wall. Biochemistry 11, 1115-1120.

TKaCZ, J. S. \& Lampen, J. O. (1972). Wall replication in Saccharomyces species: use of fluoresceinconjugated Concanavalin A to reveal the sites of mannan insertion. Journal of General Microbiology 72, 243-247.

Tkacz, J. S., Cybulska, E. B. \& Lampen, J. O. (1971). Specific stain of wall mannan in yeast cells with fluorescein-conjugated Concanavalin $\mathbf{A}$. Journal of Bacteriology 105, 1-5.

WInner, H. I. (1972). Studies on Candida. Proceedings of the Royal Society of Medicine 65, 433436. 